\title{
THE MILITARY COUP IN TURKEY ON MAY 27, 1960: BACKGROUND, DRIVERS AND IT CONSEQUENCES
}

\section{(C) 2020}

Tovsultanova Malika Sharipovna, postgraduate student of Modern and Contemporary History Department Tovsultanov Rustam Alkhazurovich, candidate of historical sciences, associate professor of Modern and Contemporary History Department

Chechen State University (Grozny, Russian Federation)

Galimova Lilia Nadipovna, doctor of historical sciences, associate professor, professor of Humanities and Social-Economic Disciplines Department

Ulyanovsk Institute of Civil Aviation named after chief Marshal of aviation B.P. Bugaev

(Ulyanovsk, Russian Federation)

Abstract. In the 1950s, the Democratic Party came to power in Turkey, relying on the provincial bourgeoisie and clericals. The charismatic leader of democrats Adnan Menderes became the prime-minister. The Democratic government pursued an active foreign and domestic policy. In particular, abandoning its traditional neutrality, Turkey joined NATO and CenTO military blocs. Concessions were made to religious circles. The government also carried out large-scale reforms, for which the society was not ready, due to which an economic crisis erupted in the country, the most characteristic manifestation of which was high inflation. By introducing repressive laws against dissidents, attempts to isolate the opposition, in particular the leaders of the Republican People's Party (RPP), the Democrats pushed the latter to search for allies in the army. In the ranks of the latter, under the influence of Western agents and the dissatisfaction of the officers themselves with the situation in the country, the idea of a military coup came about on May 27, 1960. As a result of the coup, the National Unity Committee came to power, consisting of representatives of the generals and leaders of the Republican People's Party. In 1961, a new constitution was adopted at a referendum, reforming the system of legislative power in the country, after which power again passed to civilian political institutions. The leader of the military who carried out the coup, General Jemal Gürsel, became the prime minister, while the chairman of the Republican People's Party Ismet Inönübecame became the president of Turkey.

Keywords: Turkey; military coup; 1961 May 27; Democratic party; Menderes; People's Republican Party; Ataturk; reforms; Kemalism; opposition; inflation; protests; Gladio; Counter-Guerilla; National Unity Committee; constitution; referendum; Gürsel; Inönü; Turkesp; crisis; inflation; referendum; constitution.

\section{К 110-ЛЕТИЮ СО ДНЯ РОЖДЕНИЯ ПРЕПОДАВАТЕЛЯ ИСТОРИЧЕСКОГО ФАКУЛЬТЕТА КГПИ ДОРЫ НАУМОВНЫ КЕЙСЕР (1909-1972)}

(C) 2020

Храмкова Елена Ленаровна, доктор исторических наук, профессор кафедры отечественной истории и археологии

Самарский государственный сочиально-педагогический университет (г. Самара, Российская Федераиия)

Аннотащия. Статья посвящена 110-летию со дня рождения преподавателя кафедры всеобщей истории исторического факультета Куйбышевского государственного педагогического института Доры Наумовны Кейcep (07.03.1909-14.05.1972 гг.). Впервые предпринята попытка реконструкции ее биографии на основе материалов архива Самарского государственного социально-педагогического университета (СГСПУ), Центрального государственного архива Самарской области (ЦГАСО) и Самарского областного государственного архива социально-политической истории (СОГАСПИ). Научная деятельность Д.Н. Кейсер рассматривалась с привлечением библиографических источников, хранящихся в библиотеке СГСПУ, Самарской областной универсальной научной библиотеки и Российской государственной библиотеки. Впервые были подробно изучены обстоятельства и последствия защиты первой кандидатской диссертации Д.Н. Кейсер, что позволило дополнить представление о содержании политико-идеологических кампаний второй половины 1940-х начала 1950-х гг. в педагогических вузах. Удалось выявить новые документы об одном из оппонентов ее диссертации - профессоре Сызранского государственного учительского института Владимире Евгеньевиче Фаворском. В целом анализ документов по теме доказал перспективность проведения дальнейших архивных изысканий, направленных на расширение исследовательского поля исследования истории высшего исторического образования в провинции и судеб историков в послереволюционный период.

Ключевые слова: Кейсер Дора Наумовна; педагогическая интеллигенция; политико-идеологические кампании; Куйбышевский государственный педагогический институт; Самарский государственный социальнопедагогический университет; исторический факультет; персональное дело.

Данная статья связана не только с прошедшим юбилеем Доры Наумовны Кейсер - 110-летием со дня ее рождения и с естественным желанием вспом- нить одного из любимых преподавателей исторического факультета Куйбышевского педагогического института. Ее биография созвучна многим биогра- 
фиям советских преподавателей, при желании можно отыскать немало совпадений в их жизненных установках и предпочтениях. Научный и практический интерес представляют «ответы» нашей героини на предложенные «вызовы» эпохи, в которую ей пришлось жить и работать.

Реконструкция жизненного пути Д.Н. Кейсер (рис. 1) была выполнена, главным образом, на основе анализа архивных источников, выявленных в архивах СГСПУ, ЦГАСО и СОГАСПИ. Всего были изучены материалы 19 дел, большинство из которых впервые вводятся в научный оборот. Часть из них охватывает события второй половины 1940-х - начала 1950-х гг., и поэтому содержание статьи в известной мере связано с нашей предыдущей публикацией, посвященной профессору С.Г. Басину.

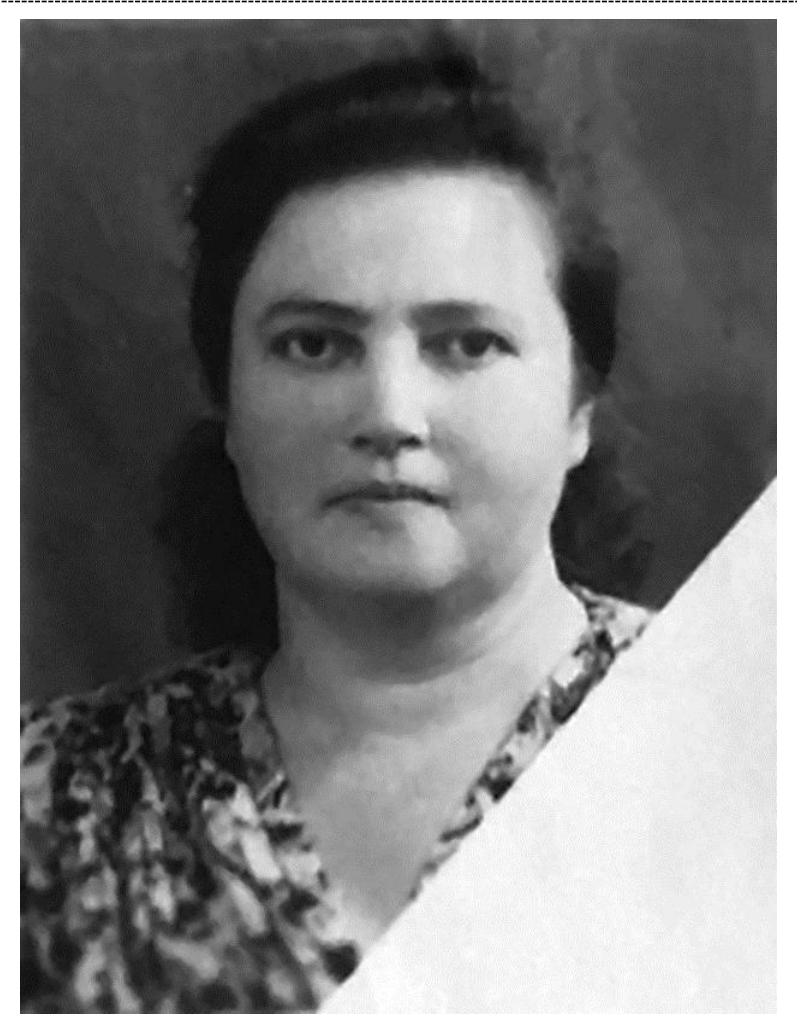

Рисунок 1 - Кейсер Дора Наумовна

В архиве СГСПУ хранится личное дело Д.Н. Кейсер. На самом деле это два личных дела (сохранились две обложки с разными датами), вложенные в одно дело. Листы первого дела, датированного октябрем 1944 г. - сентябрем 1951 г., пронумерованы; во втором деле (30 сентября 1954 г. - 1969 г.) нумерация отсутствует. Поэтому в ссылках в статье на личное дело Кейсер в одних случаях будут указаны номера листов, а в других - только дело. Нельзя не отметить, что заявления, автобиографии, личные листки по учету кадров и некоторые другие документы, заполненные замечательным почерком Доры Наумовны, отличаются отсутствием грамматических, стилистических ошибок. Это резко контрастирует с другими текстами (протоколами, выписками из протоколов, характеристиками и пр.) в ее личных, персональных делах и другой документации. Тексты Д.Н. Кейсер отличаются четкими формулировками, исключающими возможность для иных толкований. В период политико-идеологических кампаний второй половины 1940-х - начала 1950-х гг. она никогда не пыталась обвинить кого-либо еще в своих «поли- тических ошибках», и если признавала обвинения в свой адрес, то признавала без всяких оговорок.

Трагические страницы биографии Д.Н. Кейсер восстановлены на основе рассекреченных протоколов заседаний бюро Куйбышевского обкома ВКП(б) [1-3], Фрунзенского райкома (б) [4], материалов персональных дел Д.Н. Кейсер [5; 6], хранящихся в СОГАСПИ. Значительную ценность представляет рецензия сотрудника Института Маркса-ЭнгельсаЛенина при ЦК ВКП(б) (ИМЭЛ) М.В. Кабанова на рукопись книги Д.Н. Кейсер [7]. Она позволяет составить представление о структуре, проблематике, содержании ее первой кандидатской диссертации, к сожалению, утраченной, а также о предъявляемых ей обвинениях в период борьбы с «буржуазным влиянием», «космополитизмом» и др. Интересные сведения об источниковой базе упомянутой диссертации были обнаружены в личных делах Кейсер в фонде бывшего государственного архива Куйбышевской области, находящиеся в ЦГАСО [8; 9]. К наиболее информативным делам, свидетельствующим о борьбе Д.Н. Кейсер за свою работу, отвергнутую как «грубую политическую ошибку», несомненно, относится дело № 279, сохранившееся в СОГАСПИ [10].

В качестве дополнительных источников были использованы личные дела мужа и дочери Д.Н. Кейсер - Герша Нухимовича (Григория Наумовича) и Лены Гершевны Рутбергов [11-14], а также первого оппонента по диссертации Доры Наумовны профессора В.Е. Фаворского [15-17].

Важным источником явились материалы «устной истории» - воспоминания о Д.Н. Кейсер ныне здравствующих и ушедших из жизни бывших студентов Куйбышевского государственного педагогического института (КГПИ). Среди них доктор исторических наук, профессор Куйбышевского (Самарского) государственного университета Ленар Васильевич Храмков (1934-2009); кандидат исторических наук, доцент Самарского университета Галина Сергеевна Шерстнева; кандидат исторических наук, профессор СГСПУ Нина Петровна Храмкова; бывший учитель истории Валентина Григорьевна Королева; учитель истории и обществознания школы № 89 г. Самары Ида Яковлевна Браверман. Все они с неизменной теплотой, уважением вспоминали Д.Н. Кейсер как одного из самых любимых педагогов; отмечали ее скромность, доброе отношение к студентам. Также были привлечены фотоматериалы из личных дел Д.Н. Кейсер, личного архива Л.В. и Н.П. Храмковых, одну из фотографий Доры Наумовны предоставил декан факультета математики, физики и информатики СГСПУ В.Н. Аниськин.

В библиотеке СГСПУ, Самарской областной универсальной научной библиотеке и Российской государственной библиотеке были изучены сохранившиеся публикации [18-22] и автореферат кандидатской диссертации Д.Н. Кейсер [23], которые дают пусть и неполное представление об основных направлениях научной деятельности преподавателя.

Дора Наумовна родилась 7 марта 1909 г. на Украине в селе Стрижавка Винницкого района Винницкой области в семье мелкого торговца и домохозяйки. В возрасте 9 лет лишилась отца. До 15 лет девочка находилась на иждивении старших сестер-портних. В 1925 г. она окончила школу-семилетку в родном селе и поступила на школьное отделение Укра- 
инского педагогического техникума в г. Винница, который окончила в 1929 г., получив специальность учителя начальной школы. Здесь же в 1926 г. она вступила в комсомол.

Ее педагогическая деятельность началась в 20 лет в начальной школе села Потоки (Жмеринский район, Винницкая область). Проработав год, Дора переехала в село Браилов (там же), где в 1930-1933 гг. преподавала историю в старших классах семилетней школы. Одновременно в 1932-1933 гг. она являлась пропагандистом Винницого горкома ВЛКСМ. Горком направил ее на трехмесячные курсы повышения квалификации, после чего Д.Н. Кейсер в течение двух лет (1933-1935 гг.) преподавала историю в строительном техникуме г. Винница.

Высшее образование Д.Н. Кейсер получила в Винницком пединституте: в 1931 г. поступила на исторический факультет (училась сначала заочно, потом очно). В ее личном деле в архиве СГСПУ сохранилась нотариально заверенная копия диплома, заполненная от руки на украинском языке, датированная 18 мая 1953 г. За время обучения она сдала 22 экзамена, прошла педагогическую практику и защитила на «отлично» дипломную работу по истории партии большевиков в годы Первой мировой войны. Ей была присвоена квалификация преподавателя историко-экономических дисциплин в средней школе. Копия диплома производит странное впечатление: выставленные оценки свидетельствуют о том, что Дора Наумовна училась довольно плохо - по 13 предметам у нее стоят «3», по шести - «4», по трем - «2» (?!) и ни одной оценки «5». Однако расшифровка оценок, поставленных прописью, говорит о другой успеваемости - нет ни одной оценки «неудовлетворительно», 3 - «удовлетворительно» («посер.»), 13 - «хорошо» («добре») и 6 - «отлично» («відмінно»). Очевидно, что верны именно эти оценки, так как Дору Наумовну оставили работать в пединституте, и с 1 сентября 1935 г. по 3 июля 1941 г. старший преподаватель Д.Н. Кейсер читает курс по новой истории. В 1937-1940 гг. она заведует кафедрой всеобщей истории. Преподавательскую деятельность Дора Наумовна сочетала с общественной деятельностью: в 1937-1941 гг. - ответственный секретарь, затем председатель Винницкого обкома союза работников высшей школы и научных учреждений. В 1939 г. она становится членом ВКП(б) и поступает в аспирантуру по специальности «Новая история» при Московском институте философии, литературы и истории (МИФЛИ), где, несмотря на то что проучилась только год, сдала экстерном «кандидатский минимум» и приступила к работе над диссертацией на тему: «Баденское восстание в мае-июне 1849 года». Как отмечала Д.Н. Кейсер в автобиографии, работа не была написана в связи с начавшейся войной, эвакуацией и отсутствием необходимых источников и литературы. Вместе с мамой (умерла в 1946 г.) и тремя малолетними детьми - дочкой Леной и двумя племянницами (от покойной сестры) ее эвакуировали в Куйбышевскую область. В 1941-1942 гг. Д.Н. Кейсер работала учителем истории и директором Инзенской средней школы (ныне Ульяновская обл.); семья проживала в помещении школы. С сентября 1942 г. по 1948 г. Дора Наумовна являлась научным сотрудником партийного архива Куйбышевского обкома КПСС [24, л. 2-2 об., 3-3 об.; 25; 26, стб. 82; 11, л. 4 об.; 8, л. 1,$2 ; 9$, л. 1, 2]. Ее научно-исследовательская деятельность в архиве в военный период рассмотрена в статье Е.М. Малинкина [27, с. 23]. В 1945 г. Д.Н. Кейсер была награждена медалью «За доблестный труд в Великой Отечественной войне 1941-1945 гг.» [25].

Согласно сохранившемуся заявлению, 28 июля 1944 г. Дора Наумовна обратилась к директору КГПИ с просьбой о зачислении ее на внештатную должность старшего преподавателя по новой истории стран Востока (с почасовой оплатой). На заявлении содержится пометка Н.Л. Шиммеля (зам. директора по учебной части) - «Зачислить с 1 октября 1944 г.» [24, л. 1]. Так она стала работать на историческом факультете. В личном листке по учету кадров этого времени Д.Н. Кейсер отметила владение четырьмя языками: немецким, еврейским (очевидно, идиш), русским и украинским. Проживала вместе с семьей вплоть до своей кончины на улице Фрунзе, д. 56, кв. 1.

Как выглядела Д.Н. Кейсер в глазах руководства института в те годы? В известной мере показательной является копия характеристики, составленная директором КГПИ И.А. Мальцевым и секретарем партбюро института Ф.Я. Водоватовым в 1947 г. (до защиты ее диссертации), в которой она рассматривалась как «опытный и высококвалифицированный преподаватель», чьи лекции «насыщены богатым историческим материалом, дают правильные марксистско-ленинские обобщения», уделяющий много внимания научно-исследовательской работе и пользующийся «заслуженным авторитетом в коллективе профессоров, преподавателей и студентов института». Содержание ее диссертации не вызывало в характеристике никаких нареканий. Положительно оценивалась и активная общественная и партийная работа Д.Н. Кейсер «в качестве лектора обкома ВКП(б), руководителя кружка по изучению истории партии» $[24$, л. 6]. Пройдет совсем немного времени, и зазвучат совсем другие оценки ее деятельности..

В военные годы Д.Н. Кейсер начала работу над новой кандидатской диссертацией, но не по всеобщей, а по отечественной истории - истории коллективизации, которую она попыталась рассмотреть на примере Средне-Волжского края. Как нам кажется, выбор темы был связан не только с «заказом» партийного архива, но и с тем, что в юности она принимала участие в коллективизации на Украине. Как известно, в Средне-Волжский край входили восемь округов: Самарский, Сызранский, Ульяновский, Пензенский, Кузнецкий, Бугурусланский, Оренбургский, Мордовский (в 1930 г. преобразован в автономную область) [28]. Основу источниковой базы исследования составили впервые привлеченные автором архивные документы Куйбышевского партархива и госархива, материалы местной печати, выступления руководителей Средне-Волжского крайкома ВКП(б), в частности, А.Ф. Горкина [5, л. 7; 9, л. 1-6; 27, с. 23].

Об обстоятельствах защиты кандидатской диссертации Д.Н. Кейсер свидетельствует копия выписки из протокола заседания Ученого совета от 20 ноября 1947 г. [24, л. 5] и материалы ее персонального дела [5, л. 2, 6, 7-7 об.]. Предварительное обсуждение рукописи работы состоялось в местном партийном архиве на совещании научных работников и на заседании кафедры основ марксизма-ленинизма под руководством С.Т. Аздуни в КГПИ. Был высказан ряд замечаний, что привело к переработке текста диссертации. В итоге кандидатская диссертация Д.Н. Кейсер на тему: «Большевики Средней Вол- 
ги в борьбе за коллективизацию сельского хозяйства» была защищена 20 ноября 1947 г. на заседании Ученого совета КГПИ под председательством директора вуза И.А. Мальцева. Научным руководителем соискателя был доктор исторических наук, профессор Михаил Иосифович Гришин (1893 г. - ?). Дора Наумовна писала, что его «выделило» Министерство высшего образования [5, л. 7-7 об.], но, скорее всего, она познакомилась с М.И. Гришиным (в то время профессором кафедры марксизма-ленинизма МИФЛИ) во время учебы в аспирантуре. Официальными оппонентами являлись профессор Владимир Евгеньевич Фаворский и кандидат исторических наук, доцент Ефрем Игнатьевич Медведев. Если о Е.И. Медведеве как оппоненте по кандидатским диссертациям, защищавшимся в КГПИ во второй половине 1940-х гг., нам уже приходилось писать [29, с. 237], то о В.Е. Фаворском известно мало. В его личных делах, хранящихся в фонде бывшего Государственного архива Куйбышевской области (ЦГАСО), не указана его ученая степень; отсутствует перечень научных трудов [15; 16]. Публикации В.Е. Фаворского отсутствуют в местных и федеральных библиотеках. Из материалов его личного дела в Сызранском филиале ЦГАСО мы узнали, что В.Е. Фаворский родился в 1893 г. (дата кончины неизвестна); окончил в 1917 г. историко-филологический факультет Киевского университета; преподавал во многих учебных заведениях в городах Киев, Харьков, Свердловск, Самарканд, Алма-Ата, Ашхабад и др. В 19451948 гг. он заведовал кафедрой истории в Сызранском государственном учительском институте [17, л. 12-12 об., 14]. Итоги голосования на защите были следующими: за присуждение Д.Н. Кейсер ученой степени кандидата исторических наук проголосовали 12 членов Ученого совета, «против» - 2 [24, л. 5].

Партийный архив был заинтересован в издании диссертации в виде очерков («Большевики Средней Волги в борьбе за коллективизацию сельского хозяйства (от XV до XVI съезда ВКП(б)»). Они предназначались для массового читателя. Рукопись отправили на рецензирование в ИМЭЛ. Рецензию Д.Н. Кейсер получила 16 февраля 1948 г. Как сообщал заведующему партийным архивом Куйбышевского обкома ВКП(б) И. Костину заместитель заведующего Центральным партийным архивом (ЦПА) по местным архивам П.Н. Караваев, рецензию составил научный сотрудник сектора истории партии ИМЭЛ М.В. Кабанов. Она получила одобрение как указанного сектора, так и секции местных архивов ЦПА [7, л. 1]. Рамки статьи позволяют выделить наиболее существенные замечания рецензента, которые повлияли на судьбу автора очерков. Композиционно рецензия делилась на 3 части: вводную, общие замечания об очерках и замечания по главам и разделам работы. Во вступлении рецензент, нарушая логику изложения, кратко отметив новизну темы исследования, обширную источниковую базу, не вызывающую замечаний структуру книги, сразу сделал вывод о недостатках «принципиального характера», что делает невозможным издание очерков «для массового читателя». Любопытно, что уже на первой странице рецензии М.В. Кабанов с плохо скрытым раздражением высказал главное замечание: «Не скупился автор в использовании материала, отражающего ошибки и искривления политики партии в колхозном движении» [7, л. 2]. Материал рецензии, с одной стороны, весьма ярко отражает историографическую ситуацию рассматриваемого периода в области изучения коллективизации в СССР, а с другой стороны, позволяет увидеть, как отдельные историки колхозного движения (в их числе оказалась и Д.Н. Кейсер) нарушали устоявшиеся стереотипы. Интересно, что сама Дора Наумовна, по-видимому, довольно долго не усматривала в своей работе никакой «крамолы».

Рецензент, подробно рассмотрев основные аспекты проблемы, затронутые с разной степенью полноты в очерках, пришел к выводу о том, что автор не справилась с огромным фактическим материалом. По его мнению, это выразилось в поверхностном освещении некоторых вопросов (например, «идеологической работы партийных организаций среди крестьянских масс»); в слишком «щедрых» (М.В. Кабанов) примерах, которые создают неправильное впечатление у читателя о роли Советов, партийных организаций, деятельности уполномоченных крайкома ВКП(б), «двадцатипятитысячников» в годы коллективизации в Средневолжском крае [7, л. 4, 5, 14, 15, 17]; в создании неуместных таблиц: «Погоня за количеством» (речь идет о форсированном создании коллективных хозяйств), «Картина отливов» (выход крестьян из колхозов) [7, л. 7]. К грубым политическим ошибкам рецензент отнес терминологию, которой оперировала Д.Н. Кейсер: «массовые перегибы», «массовые искривления», «повальные обыски», «повсеместный выход из колхозов», «массовые выступления против колхозов», «массовый распад колхозов», «головотяпство партийных организаций», «извращение партийной линии» и др., а также попытку расслышать «голоса» недовольных коллективизацией крестьян. Судя по приведенным в рецензии примерам, Д.Н. Кейсер с присущей ей добросовестностью пыталась понять мотивы их поведения, реакцию на происходившие события, которые привели к обострению классовой борьбы в деревне в 19281929 гг. [7, л. 5, 11-13].

Теоретические ошибки рецензент увидел в авторской трактовке коллективизации, которая противоречит концепции, содержащейся в «Истории Всесоюзной Коммунистической Партии (большевиков). Краткий курс» и в статьях И.В. Сталина «Головокружение от успехов. К вопросам колхозного движения», «Ответ товарищам колхозникам». М.В. Кабанов пришел к выводу о том, что «автор не продумал до конца сложности явлений в процессе социалистической перестройки сельского хозяйства», что привело, в свою очередь, к искажению действительного исторического процесса 1929-1931 гг. [7, л. 5, 6, 17]. Поэтому очерки нуждаются в кардинальной переработке и в повторном предоставлении в ИМЭЛ для решения вопроса о возможности их публикации [7, л. 21].

Безусловно, наиболее интересным является вопрос: как, разделяя общий традиционный для второй половины 1940-х гг. подход к оценке исторического значения коллективизации в нашей стране, не сомневаясь в ее необходимости, Д.Н. Кейсер в своей работе позволила «заговорить» «кулакам», критиковала действия государственных и партийных органов власти на местах? Изученные документы не дают возможности говорить о ее «отклонениях» от партийной линии. Как нам кажется, в данном случае важную роль сыграли личные и профессиональные качества историка и та источниковая база, с которой работала Кейсер. Ряд документов, недоступные рядовым посетителям архива, были выданы ей, как научному сотруднику партархива. По-видимому, материалы, со- 
держащие негативную информацию о восприятии крестьянством форм и методов коллективизации, способствовали частичному отступлению Д.Н. Кейсер от традиционной концепции «великого перелома» в сельском хозяйстве.

В объяснительном письме, написанном 16 мая 1949 г., Д.Н. Кейсер с предельной честностью перечислила главные ошибки, выделенные рецензентом ИМЭЛ. Она подчеркивала, что в своем исследовании привела «дословные высказывания кулаков и других враждебных элементов», но «это было сделано не со злым умыслом». Она полагала, что тем самым она показывала, «как большевики Средней Волги боролись с кулаками». Допущенные «ошибки» повлекли за собой появление «Дела Кейсер», которое являлось предметом разбирательства не менее пяти раз (!) в пединституте (11 и 26 апреля 1949 г. - на партбюро КГПИ; 6, 12-13 и 26 апреля 1949 г. - на партийных собраниях исторического факультета и пединститута) [5, л. 7-7 об., 8]. Остановимся на наиболее важных фактах с точки зрения дальнейшей судьбы Д.Н. Кейсер.

26 апреля 1949 г. «дело» старшего преподавателя кафедры всеобщей истории Д.Н. Кейсер обсуждалось на заседании партбюро КГПИ одновременно с аналогичными делами коллег - С.Г. Басина и А.Я. Ротковича. Дора Наумовна обвинялась «в принижении роли партийных, советских, комсомольских организаций в борьбе за коллективизацию в Поволжье», в неправильном истолковании известной статьи И.В. Сталина «Головокружение от успехов. К вопросам колхозного движения», опубликованной 2 марта 1930 г.; «в совершенно ненужном показе антисоветской пропаганды кулаков». На заседании выслушали и Д.Н. Кейсер, которая заявила, что она допустила «вольные или невольные грубые политические ошибки; она полагала, что в своей работе она раскрывает «маневры врага», однако на самом деле «дала трибуну для антисоветских выступлений». Некоторые из присутствующих, несомненно, уловили, что в диссертации были использованы источники, позволявшие судить о настроениях «кулаков». Сомнение вызывает достоверность ответа Д.Н. Кейсер на вопрос об оппонентах ее диссертации. В протоколе написано, что она назвала фамилии Фаворского, Медведева, Аздуни, Гришина. Разумеется, Дора Наумовна не могла так ответить, так как ей были хорошо известны имена собственного научного руководителя - М.И. Гришина, оппонентов - В.Е. Фаворского и Е.И. Медведева. С.Т. Аздуни (зав. кафедрой основ марксизма-ленинизма КГПИ до 1948 г.) консультировал ее в ходе работы над диссертацией. Члены партбюро поинтересовались, почему она защищала диссертацию не по специальности (не по всеобщей истории). Д.Н. Кейсер ответила, что периодом коллективизации она заинтересовалась давно, так как она «сама была участницей этой большой работы». К сожалению, причастность Кейсер к проведению коллективизации в изученных документах не отражена. Мы предполагаем, что она могла участвовать в этом, когда работала учителем или пропагандистом горкома комсомола в конце 20 -х - начале 30 х гг. в Винницкой области. В любом случае она не понаслышке знала о том, что такое коллективизация и раскулачивание крестьянства. По «делу Кейсер» на заседании партбюро выступили В.С. Чепурнов (зам. директора КГПИ по учебно-научной части), Ф.А. Буранов (зав. кафедрой основ марксизма-ленинизма) и В.А. Стальный (зав. кафедрой всеобщей истории).
Общим в их выступлениях было обвинение Д.Н. Кейсер в политических ошибках, но имелись и отличия. В.А. Стальный, как и в других подобных случаях, пытался хоть как-то защитить от нападок кафедру (говорил, что «провинившаяся» начала работать над диссертацией «еще до поступления в институт») и обвиняемого преподавателя. Он подчеркнул, что Дора Наумовна очень тщательно готовится к лекциям, «не допускает ошибок, пользуется авторитетом...», и предложил вынести ей выговор с занесением в личное дело. Иная точка зрения была у В.С. Чепурнова. Когда удавалось выявить серьезные просчеты политического характера в диссертациях коллег, он предлагал одно действенное, по его мнению, средство обсудить диссертацию на Ученом совете института и довести принятое решение до Высшей аттестационной комиссии, иными словами - ходатайствовать о не присуждении ученой степени кандидата исторических наук Д.Н. Кейсер, несмотря на то, что диссертация была успешно защищена. Разумеется, он предлагал объявить Кейсер строгий выговор. Но большинство членов партбюро в этой части наказания с ним не согласилось. В итоге в постановлении партбюро прозвучало решение объявить Д.Н. Кейсер выговор с занесением в учетную карточку. За это решение проголосовали 8 человек из 10 .

Решение партбюро немедленно было доведено до парткома КГПИ, и в тот же день (26 апреля) на закрытом партийном собрании под председательством В.С. Чепурнова вновь заслушали персональные дела трех упомянутых преподавателей. На собрании, как указано в выписке из протокола, не прозвучало ни одного выступления и не было задано ни одного вопроса. В постановляющей части практически полностью повторяется постановление партбюро, за исключением предложения о необходимости «ходатайствовать перед Фрунзенским РК ВКП(б) об утверждении данного решения». Излишне говорить о том, что решение в отношении Д.Н. Кейсер было принято единогласно [5, л. 2-5]. К «делу Кейсер», которое было направлено во Фрунзенский райком партии, кроме выписок из двух протоколов заседаний партбюро и партийного собрания КГПИ, была приложена характеристика, датированная 13 мая 1949 г. и подписанная секретарем партбюро вуза И.А. Павловым. В ней с ошибками указаны название родного села Д.Н. Кейсер и год начала ее работы в пединституте; отмечена ее общественная работа (председатель месткома КГПИ). Повторяя уже известные нам обвинения, И.А. Павлов от себя добавил еще одно обвинение: из диссертации Д.Н. Кейсер следует, что статья вождя «Головокружение от успехов» якобы «послужила толчком к массовому отливу крестьян из колхозов» [5, л. 6].

21 мая 1949 г. «дело Кейсер» поступило во Фрунзенский райком партии, а его обсуждение состоялось 1 июня на заседании бюро, где должны были утвердить решение партийной организации КГПИ. Однако все сложилось иначе. Вместе с Д.Н. Кейсер заслушивались дела еще двух преподавателей пединститута, которых осуждали за «допущенные ошибки космополитического характера» (Я.А. Роткович), «грубые политические ошибки» в кандидатской диссертации (С.Г. Басин). Оба в целом признавали свои ошибки Ситуация с Д.Н. Кейсер была не столь однозначной. Отметив, что в личном объяснении (имелось в виду письмо Д.Н. Кейсер от 16 мая 1949 г., адресованное Фрунзенскому райкому партии) она признает допу- 
щенные грубые политические ошибки и «дает слово, что на деле сумеет исправить их», но при этом не признает, что неправильно осветила работу И.В. Сталина, и «в этой части... не согласна с постановлением парторганизации». Не ожидавшие этого, не привыкшие хотя бы к малейшему сопротивлению обвиняемых, члены бюро оценили поведение Кейсер как «непартийное» и единогласно приняли решение изменить постановление, принятое КГПИ: вместо выговора ей объявили строгий выговор с занесением в учетную карточку [4, л. 62-62 об.; 5, л. 1-1 об., 7-8 об.].

Трудно представить, что пережила в эти дни Дора Наумовна, тем более учитывая тот факт, что она узнала, что 28 мая 1949 г. ВАК отменил решение Ученого совета Куйбышевского педагогического и учительского института им. В.В. Куйбышева от 20 ноября 1947 г. о присуждении ей ученой степени кандидата исторических наук. В сохранившейся заверенной копии выписки из протокола заседания ВАК указана причина такого решения - «представленная к защите работа не отвечает требованиям, предъявляемым к диссертации на соискание ученой степени кандидата наук». Ученому совету пединститута предлагалось обсудить принятое постановление ВАК, обратив самое пристальное внимание на «безответственное отношение Совета Института и официальных оппонентов при оценке диссертации Кейсер Д.Н., содержащей серьезные политические ошибки». Слева на копии выписки рукой директора КГПИ А.Я. Буровиной сделана пометка: «Ознакомить Чепурнова... и довести до сведения Ученого Совета» [24, л. 4-4 об.]. Именно В.С. Чепурнов инициировал отправку в ВАК соответствующей бумаги об «ошибках» Д.Н. Кейсер.

Конечно, встает вопрос о том, пыталась ли Д.Н. Кейсер исправить свою работу. В начале мая 1949 г. В.С. Чепурнов, как исполняющий обязанности директора КГПИ, обратился к секретарю Куйбышевского обкома партии А.И. Деревнину с просьбой разрешить старшему преподавателю пединститута Д.Н. Кейсер работать в партийном архиве с целью переработки кандидатской диссертации «в соответствии с рецензией сектора истории партии ИМЭЛа» $[10$, л. 1]. 3 июня она подписала обязательство «хранить в строжайшем секрете государственные тайны..., а также все сведения, касающиеся документов партархива», и начала изучать документы, хранившиеся в фондах Самарского губкома, крайкома, райкомов ВКП(б), политотдела МТС и др. [10, л. 2-3]. Сохранилось несколько требовательных листов и выписки, которые делала Д.Н. Кейсер. Из них следует, что ее интересовали, главным образом, документы 1933-1934 гг. Она осталась верна себе: попрежнему обращала внимание на негативные моменты в проведении коллективизации на Средней Волге, в данном случае в деятельности политотделов [10, л. 10]. Сохранился и новый план диссертации, датированный 7 сентября 1951 г. Рукопись должна была состоять из трех глав: «Сельское хозяйство Средней Волги накануне сплошной коллективизации», «Средне-Волжская партийная организация в борьбе за реализацию решений партии о коллективизации сельского хозяйства» и «Дальнейший рост колхозного движения. Борьба за организационно-хозяйственное укрепление колхозов». Обращает на себя внимание пятый параграф второй главы исследования, в котором она вновь собиралась рассматривать борьбу «с искривлениями политики партии в колхозном движении», а затем на этой основе перейти к новому подъему колхозного движения и завершению сплошной коллективизации в Среднем Поволжье [10, л. 21-22].

Следует отметить, что партийная организация пединститута и руководство партархива внимательно следили за попытками Д.Н. Кейсер исправить свою работу. Об этом, в частности, свидетельствует официальное письмо секретаря партбюро КГПИ А.Д. Паршиковой, адресованное заведующему областным партийным архивом И. Костину (возглавлял архив в 1946-1956 гг.), датированное маем 1951 г., в котором она просила дать справку об исправлении ошибок, допущенных ранее Д.Н. Кейсер при написании диссертации. И. Костин отреагировал немедленно, собственноручно написав 29 мая на бланке письма следующее: «... т. Кейсер работу не исправила» [10, л. 4]. В тот же день им было написано более подробное официальное письмо на имя А.Д. Паршиковой, в котором он информировал: Д.Н. Кейсер как научный сотрудник архива по заданию Е.И. Шатуновой (первый директор партархива) писала работу по истории коллективизации на Средней Волге. В работе были «допущены серьезные политические ошибки, поэтому ИМЭЛ не разрешил партархиву издать эту работу и предложил ее переработать, устранить ошибки, после чего представить в ИМЭЛ на вторичный просмотр и только после этого сдать в печать». И. Костин отметил, что со времени рецензии ИМЭЛ (3 февраля 1948 г.) прошло более трех лет, но «Кейсер к переработке ее и устранению допущенных ошибок не приступила». Мало того, она представляла ее как диссертацию. Подытоживая сказанное, И. Костин подчеркнул: партархив «категорически возражает против того, чтобы т. Кейсер представляла вышеуказанную работу, принадлежащую партархиву обкома ВКП(б), как свою диссертацию». Разумеется, Д.Н. Кейсер была ознакомлена с текстом письма и знала о том, что оно было согласовано И. Костиным с секретарем обкома партии А.И. Деревниным [10, л. 5-6]. Видимо, после этого она решила не защищать во второй раз диссертацию по указанной теме.

4 июля 1951 г. на заседании бюро Фрунзенского РК ВКП(б) вновь слушалось «дело» старшего преподавателя кафедры всеобщей истории КГПИ Д.Н. Кейсер в связи с ее заявлением в партийную организацию института с просьбой снять с нее партийное взыскание. 25 июня 1951 г. первичная парторганизация рассмотрела это заявление и единогласно поддержала просьбу Кейсер [6, л. 1-3]. Фрунзенский райком партии, в свою очередь, подтвердил снятие строгого выговора за допущенные грубые политические ошибки в ее кандидатской диссертации [4, л. 94-94 об.].

Завершение «дела» совпало с увольнением Д.Н. Кейсер по приказу дирекции КГПИ в конце 1950-1951 учебного года. На половине листа без нумерации, вшитом в первое личное дело в архиве СГСПУ, указано - «в связи с сокращением объема работ» [24]. 4 сентября 1951 г. на заседании бюро Куйбышевского обкома ВКП(б) она была утверждена в должности старшего преподавателя основ марксизма-ленинизма в Куйбышевском филиале Всесоюзного юридического института (ВЮЗИ) [1, л. 5]. 5 сентября директор филиала А.М. Даниелян обратился к секретарю парторганизации КГПИ А.Д. Паршиковой с просьбой дать партийную характеристику 
на Дору Наумовну. В предоставленной ему характеристике подчеркивалось хорошее владение Кейсер материалом преподаваемых ею дисциплин - новой истории и новой истории стран Востока (лекции и семинарские занятия), активное участие в общественной работе КГПИ в качестве председателя месткома, внештатного пропагандиста Фрунзенского РК ВКП(б) и др. Также директор филиала ВЮЗИ был проинформирован о строгом партийном выговоре Д.Н. Кейсер, вынесенном 1 июня 1949 г., и его снятии в 1951 г. [24, л. 7, 8-8 об.].

2 ноября 1951 г. на заседании бюро Куйбышевского обкома ВКП(б) Д.Н. Кейсер освободили от работы в филиале ВЮЗИ и утвердили в должности ассистента кафедры основ марксизма-ленинизма Куйбышевского гидротехнического института [2, л. 6]. 5 сентября 1952 г. на аналогичном заседании приняли решение назначить на место Д.Н. Кейсер историка Л.И. Байдину [3, л. 8]. Следует отметить, что, несмотря на то что Дора Наумовна перестала на некоторое время работать на очном отделении истфака КГПИ, в 1951-1954 гг. она трудилась почасовиком: читала студентам-заочникам курс по новой истории. В сентябре 1954 г. она вновь стала штатным преподавателем кафедры всеобщей истории в пединституте.

В 1951 г. Д.Н. Кейсер во второй раз сдала кандидатский минимум, а в 1957 г. в Московском государственном педагогическом институте им. В.И. Ленина под руководством крупного специалиста по истории Франции, доктора исторических наук, профессора Александра Ивановича Молока (1898-1977) защитила кандидатскую диссертацию по методике преподавания всеобщей истории [23]. Следует подчеркнуть, что ее всегда отличал интерес к проблемам методики [18-21]; в течение многих лет она руководила педагогической практикой на историческом факультете КГПИ, хорошо понимала трудности, с которыми сталкивались молодые учителя в школе. Она неоднократно выступала перед учителями с докладами по вопросам методики на областных августовских совещаниях, семинарах руководителей школьных методических объединений и преподавателей истории при Куйбышевском городском институте усовершенствования учителей [23, с. 16]. Работа Д.Н. Кейсер была основана на многолетнем личном опыте преподавания истории в школе и педагогическом институте, педагогическом эксперименте, который проводился в 1950-х гг. в школах городов Куйбышева, Москвы, Куйбышевской области, в том числе с применением методических разработок автора диссертационного труда [23, с. 4]. Со времени защиты Д.Н. Кейсер прошло более полувека, но не потеряли актуальности ее некоторые замечания и выводы относительно программы, учебника, методического пособия по новой истории, методов и приемов, используемых учителями для раскрытия отдельных вопросов изучаемого периода [23, с. 6, 7, 9, 10].

В начале 1970-х гг. ее перевели на почасовую оплату в КГПИ; она продолжала вести педагогическую практику на историческом факультете. 14 мая 1972 г. Дора Наумовна Кейсер безвременно скончалась в возрасте 63-х лет [25].

O ее семье: муже и дочери, внуках и правнуках рассказано в статье А.А. Перчикова [30]. Но мы убеждены в том, что для восполнения пробела в ис- тории самарской высшей школы должна быть написана научная биография известного самарского историка, участника Великой Отечественной войны Григория Наумовича (Герша Нухимовича) Рутберга (1906-1988) - доктора исторических наук, профессора, заведующего кафедрой истории КПСС Куйбышевского государственного медицинского института.

В заключение хочется сказать следующее: биография Д.Н. Кейсер, несомненно, покажется кому-то заурядной, не заслуживающей особого внимания, но именно такие, как она, во многом определяли «лицо» провинциальных вузов в советский период, воспитывая студентов повседневным ответственным отношением к чтению лекций, проведению семинарских занятий, педагогической практики, убежденностью в нужности учительской профессии. Жаль, что оказалась утраченной ее диссертация по истории коллективизации. Спустя 22 года младший коллега Д.Н. Кейсер, будущий профессор Федор Андрианович Каревский защитил докторскую диссертацию на тему, которая так много значила в ее жизни [31]. Не считая корректным сравнивать обе диссертации, отметим, что Ф.А. Каревский, безусловно, знал о судьбе работы Д.Н. Кейсер. Писать и защищать свою громадную диссертацию (2 тома) ему пришлось совсем в другое время - в период начала и на излете «оттепели». Несмотря на то, что Ф.А. Каревскому удалось создать фундаментальный труд по истории коллективизации в Среднем Поволжье, интересные поиски Д.Н. Кейсер не нашли отклика в его труде.

\section{Благодарности}

Благодарим за помощь, оказанную нам сотрудниками самарских архивов: Евгения Михайловича Малинкина, Людмилу Александровну Панкратову (СОГАСПИ); Павла Семеновича Лебединского (ЦГАСО); зав. архивом СГСПУ Тамару Алексеевну Пенину и зав. библиотекой СГСПУ Людмилу Александровну Киселеву.

\section{Список литературы:}

1. Самарский областной государственный архив социально-политической истории (СОГАСПИ). Ф. 656. Оп. 77. Д. 111.

2. СОГАСПИ. Ф. 656. ОП. 77. Д. 143.

3. СОГАСПИ. Ф. 656. ОП. 79. Д. 110.

4. СОГАСПИ. Ф. 656. ОП. 120. Д. 989.

5. СОГАСПИ. Ф. 1328. ОП. 18. Д. 408.

6. СОГАСПИ. Ф. 1328. ОП. 26. Д. 259.

7. СОГАСПИ. Ф. 651. Оп. 1. Д. 31.

8. Центральный государственный архив Самарской области (ЦГАСО). Ф. Р-2189. Оп. 9. Д. 229.

9. ЦГАСО. Ф. Р-2189. Оп. 9. Д. 230.

10. СОГАСПИ. Ф. 651. ОП. 3. Д. 279.

11. СОГАСПИ. Ф. 2980. Оп. 1. Д. 219.

12. СОГАСПИ. Ф. 651. ОП. 3. Д. 546.

13. ЦГАСО. Ф. Р-4079. Оп. 7. Д. 3543.

14. СОГАСПИ. Ф. 1004. Оп. 74. Д. 566.

15. ЦГАСО. Ф. Р-2189. Оп. 9. Д. 575.

16. ЦГАСО. Ф. Р-2189. Оп. 24. Д. 191.

17. Сызранский филиал ЦГАСО. Ф. Р-421. Оп. 4. Д. 2864.

18. Кейсер Д.Н. Французская буржуазная революция XVIII века: методическая разработка уроков для 8 класса средней школы: (из опыта работы) / под ред. И.Б. Аронина. Куйбышев, 1956. 103 с. 
19. Кейсер Д.Н. Франция с 1815 по 1848 г.: (методическая разработка): в помощь начинающим учителям / под ред. И.Б. Аронина. Куйбышев, 1956. 23 с.

20. Кейсер Д.Н. К вопросу об изучении роли народных масс на уроках истории в 8 классе средней школы по теме «Французская буржуазная революция XVIII века» // Ученые зап. Куйбышевский педагогический институт. Вып. 20, ч. 3. Куйбышев, 1958. C. 81-122.

21. Кейсер Д.Н. Освещение роли народных масс в революции 1848 года во Франции в курсе истории средней школы // Некоторые вопросы преподавания истории и краеведческой работы. Куйбышев, 1961. C. 164-198.

22. Кейсер Д.Н. Помощь советской России монгольскому народу в борьбе за победу народной революции. 1921 г. // Ученые зап. Куйбышевский педагогический институт. Вып. 60. Куйбышев, 1969. С. 100-126.

23. Кейсер Д.Н. Методика изучения решающей роли народных масс в истории буржуазных революций во Франции XVIII-XIX вв. (в курсе новой истории 8 класса средней школы): автореф. дис. ... канд. пед. наук: Методика истории / МГПИ им. В.И. Ленина. М., 1957. $16 \mathrm{c}$.

\section{$1^{\text {11H }}$ ANNIVERSARY OF THE TEACHER DORA NAUMOVNA KEYSER (1909-1972) WHO WORKED AT THE FACULTY OF HISTORY AT KUIBYSHEV STATE PEDAGOGICAL INSTITUTE}

(C) 2020

Khramkova Elena Lenarovna, doctor of historical sciences, professor of Domestic History and Archeology Department

Samara State University of Social Sciences and Education (Samara, Russian Federation)

Abstract. The paper is dedicated to the $110^{\text {th }}$ anniversary of the teacher Dora Naumovna Keyser (07 March 190914 May 1972) who worked for General History Department at Kuibyshev State Pedagogical Institute. The author of this paper for the first time considers the biography of D.N. Keyser on the basis of materials from the archive of Samara State University of Social Sciences and Education, the Central State Archive of the Samara Region and the Samara Regional State Archive of Socio-Political History. D.N. Keyser's scientific activity was examined using bibliographic sources stored in the library of Samara State University of Social Sciences and Education, Samara Regional Universal Scientific Library and the Russian State Library. The author also studies the circumstances and consequences of the defense of the first $\mathrm{PhD}$ by D.N. Keyser, which made it possible to supplement the idea of the content of political and ideological campaigns of the second half of the 1940s - early 1950s at pedagogical universities. It was possible to find new documents about one of the opponents of her dissertation - Professor of Syzran State Teachers' Institute Vladimir Evgenievich Favorsky. In general, the analysis of documents proved the prospect of further archival research aimed at expanding the research field of studying the history of higher historical education in the province and the fate of historians in the post-revolutionary period.

Keywords: Keyser Dora Naumovna; pedagogical intelligentsia; political and ideological campaigns; Kuibyshev State Pedagogical Institute; Samara State University of Social Sciences and Education; history department; personal matter.

$* * *$

УДК 94 (595)

DOI 10.24411/2309-4370-2020-11217

Статья поступила в редакцию 09.12.2019

\section{РЕКОНСТРУКЦИЯ КОНФЛИКТА: ОБРАЗОВАНИЕ ИРА В ОЦЕНКАХ БРИТАНСКИХ ВОЕННЫХ}

(C) 2020

Старостин Виталий Викторович, студент исторического факультета

Самарский государственный социально-педагогический университет (2. Самара, Российская Федераџия)

Аннотация. В статье рассматриваются взгляды британских военных на процесс становления одной из первых в истории XX века военизированных организаций - Ирландской республиканской армии (ИРА). Особое внимание уделено тому, как британские военные пытались объяснить этот новый феномен. Анализируются причины неприятия британскими военными таких понятий, как «партизанская война», «ирландские повстанцы» и др. Исследуются основные причины, сформировавшие взгляды британских военных на ИРА 